\title{
Pengaruh Perilaku Kepemimpinan Lurah dan Motivasi terhadap Kinerja Pegawai Kelurahan di Kecamatan Samarinda Utara
}

\author{
Purwadi \\ Fakultas Ekonomi dan Bisnis Universitas Mulawarman, Indonesia \\ E-mail: purwadi@feb.unmul.ac.id
}

\begin{abstract}
Tujuan penelitian ini adalah untuk mengetahui pengaruh perilaku kepemimpinan lurah dan motivasi terhadap kinerja pegawai Kelurahan di Kecamatan Samarinda Utara dan untuk mengetahui variabel yang berpengaruh dominan terhadap kinerja pegawai Kelurahan di Kecamatan Samarinda Utara. Adapun alat analisis yang digunakan adalah analisis regresi linear berganda. Obyek dalam penelitian ini adalah seluruh pegawai pegawai kelurahan di Kecamatan Samarinda Utara di Kota Samarinda. Pengumpulan data dilakukan dengan kuesioner. Alat analisis yang digunakan adalah regresi liner berganda. Hasil penelitian menemukan bahwa variabel perilaku kepemimpinan lurah dan variabel motivasi berpengaruh signifikan terhadap kinerja pegawai. Dari kedua variabel tersebut, diketahui variabel motivasi berpengaruh dominan dibandingkan variabel perilaku kepemimpinan lurah.
\end{abstract}

Kata Kunci: perilaku kepemimpinan, motivasi, kinerja, Samarinda

\section{Influence of Leadership and Motivation Leadership Behavior on the Performance of Kelurahan Officers in North Samarinda District}

\begin{abstract}
The purpose of this research is to know the influence of leadership behavior of lurah and motivation to performance of kelurahan employee in North Samarinda Subdistrict and to know the dominant influence variable to performance of kelurahan employee in North Samarinda District. The analytical tool used is multiple linear regression analysis. Object in this research is all employee of kelurahan employees in North Samarinda Subdistrict in Samarinda City. The data were collected by questionnaire. The analysis tool used is multiple linear regression. The results of the study found that the variables of leadership behavior of lurah and motivation variable significantly influenced employee performance. From both variables, it is known that motivation variable has dominant influence compared to lurah leadership behavior variable.
\end{abstract}

Keywords: leadership behavior, motivation, performance, Samarinda 


\section{PENDAHULUAN}

Dalam masyarakat yang selalu berkembang, sumber daya manusia mempunyai kedudukan yang penting. Meskipun berada dalam masyarakat yang berorientasi kerja, yang melihat bahwa kerja itu sebagai sesuatu yang mulia, tidak berarti mengabaikan manusia yang melakukan kerja tersebut. Demikian juga perusahaan-perusahaan yang ingin mengembangkan usahanya untuk mendapatkan keuntungan yang maksimal, memerlukan berbagai sumber daya yang harus dikelola sebaik-baiknya agar dapat tercapai apa yang menjadi tujuan perusahaan. Tujuan perusahaan akan tercapai apabila perusahaan melakukan kegiatankegiatan dengan mengkombinasikan faktor-faktor produksi seperti tanah, gedung atau bangunan, mesin dan manusia. Faktor manusia merupakan faktor dominan, karena hampir seluruh kegiatan dalam organisasi akan sangat bergantung pada faktor tersebut.

Sebagai satu di antara faktor dominan, tentu saja dituntut untuk berubah dan berkembang. Oleh sebab itu pihak perusahaan harus bisa menggerakkan, mengarahkan dan mengkoordinasikan pegawainya sehingga dapat bekerja secara efektif dan efisien. Bila pegawai bekerja dengan lebih efektif dan efisien diharapkan kinerja perusahaan akan lebih baik sehingga produktivitas perusahaan akan naik dan menghasilkan produk yang banyak serta berkualitas. Pegawai dapat bekerja lebih efektif dan efisien apabila perusahaan memperhatikan keinginan dan kebutuhan pegawai secara terus menerus sehingga pegawai dapat bekerja lebih maksimal. Hubungan antara penilaian pegawai tentang perilaku kepemimpinan dan motivasi kerja dengan kinerja pegawai adalah berbanding lurus dimana semakin besar atau tinggi penilaian pegawai tentang perilaku kepemimpinan dan motivasi kerja, maka akan semakin tinggi pula tingkat kinerjanya, demikian pula sebaliknya semakin kecil atau rendah penilaian pegawai tentang perilaku kepemimpinan dan motivasi kerja semakin kecil atau rendah pula kinerjanya. Prestasi kerja pegawai tentu saja sangat erat kaitannya dengan kinerja sebuah organisasi, hal ini mudah dimengerti karena semakin tinggi penilaian pegawai tentang perilaku kepemimpinan dan motivasi kerja, maka kinerja pegawai tersebut akan semakin baik.

Secara garis besar ada dua perilaku kepemimpinan yaitu konsiderasi dan struktur inisiasi. Konsiderasi adalah perilaku kepemimpinan yang cenderung ke arah kepentingan bawahan, seperti ramah tamah, mendukung dan membela bawahan, mau menerima usulan bawahan dan lain-lain, sedangkan struktur inisiasi adalah perilaku kepemimpinan yang cenderung lebih mementingkan tujuan organisasi dari pada memperhatikan bawahan, seperti selalu memberi tahu apa-apa yang dikerjakan bawahan, memberikan standar tertentu atas pekerjaan dan lain-lain. Sedangkan faktor yang dapat meningkatkan motivasi kerja seseorang secara garis besar ada dua faktor, yaitu faktor material dan faktor non material. Faktor material terdiri dari faktor material langsung dan faktor material tidak langsung. Faktor material langsung terdiri dari gaji, upah, insentif, bonus, komisi, honorarium dan tunjangan keluarga. Sedangkan faktor material tidak langsung terdiri dari jaminan sosial, beasiswa, pemilikan saham, simpan pinjam, kafetaria murah dan transportasi. Sedangkan faktor non material biasanya dapat berwujud simbol misalnya, kantor yang representatif, telpon, kursi, alat transportasi, pengalaman bekerja, pendidikan dan latihan, gizi dan kesehatan terjamin, tempat parkir dan sarana lainnya untuk memudahkan dalam melaksanakan tugas-tugas kantor.

Kecamatan Samarinda Utara memiliki 11 Kantor Kelurahan dengan jumlah pegawai yang bekerja di Kantor Kelurahan sebanyak 175 orang. Pegawai yang berada di Kelurahan merupakan ujung tombak antara pemerintah dengan masyarakat yang mana ketidakpuasan pegawai kelurahan akan mengakibatkan ketidakpuasan masyarakat. Padahal sukses pemerintahan tergantung pada masyarakat yang puas dan loyal. Motivasi pegawai dapat membantu dalam memaksimalkan kinerja pemerintahan dalam jangka panjang. Dalam rangka pencapaian tujuan tersebut, maka hal mendasar yang harus dilakukan pemerintahan di Kecamatan Samarinda Utara adalah memberikan rangsangan berupa motivasi kepada pegawainya dan melalui perilaku kepemimpinan yang baik pula.

Berdasarkan penelitian pendahuluan yang penulis lakukan, diketahui bahwa Kecamatan Samarinda Utara melalui 11 Kelurahan telah menerapkan motivasi kerja kepada pegawainya melalui Lurah selaku 
pemimpin di Kelurahan. Adapun motivasi yang diterapakan Kelurahan berupa pemenuhan kebutuhan akan eksistensi (existence needs), pemenuhan kebutuhan akan persaudaraan (relationship) dan pemenuhan kebutuhan akan pertumbuhan (growth), sedangkan perilaku kepemimpinan yang diterapkan adalah keseimbangan antara inisisai dan struktur nisiasi. Struktut inisiasi adalah perilaku kepemimpinan yang cenderung lebih mementingkan tujuan organisasi dari pada memperhatikan bawahan. Hal ini dilakukan Kecamatan Samarinda Utara melalui 11 Kelurahan dengan tujuan meningkatkan kinerja pegawai yang dapat ditunjukkan melalui peningkatan kualitas yang dihasilkan pegawai, peningkatan kecepatan dan ketepatan penyelesaian pekerjaan, peningkatan kreativitas kerja pegawai serta peningkatan disiplin kerja pegawai.

Pada lingkungan pekerjaan banyak berpendapat bahwa faktor motivasi kerja lebih merupakan faktor dominan yang mempengaruhi kinerja seorang pegawai karena pada motivasi terdapat unsur pendapatan atau gaji yang merupakan hal utama alasan seseorang bekerja sehingga banyak yang memberikan gaji relatif tinggi kepada pegawainya untuk memberi motivasi mereka. Sebenarnya bila pegawai mendapatkan upah atau gaji didasarkan pada tuntutan pekerjaannya, tingkat keterampilan individu dan standar pengupahan komunitas, kemungkinan besar dan akan dihasilkan motivasi tentu tidak semua orang mengejar uang, banyak orang bersedia menerima uang yang lebih untuk bekerja di lokasi yang lebih diinginkan. William M. Mercer Inc. melalui survei terhadap 206 perusahaan menengah sampai besar di tahun 1998 menemukan bahwa di perusahaan-perusahaan dengan tingkat keluar masuknya pegawai yang tinggi, gaji merupakan faktor yang dominan terhadap ketidakpuasan pegawai sebaliknya perusahaan yang tingkat keluar masuknya pegawai sangat rendah, bertahannya para pegawai $40 \%$ disebabkan oleh faktorfaktor yang bersifat emosional dibanding faktor gaji atau pendapatan yang hanya $21 \%$. Faktor emosional tersebut adalah motivasi dalam bekerja, hubungan baik dengan atasan dan pegawai lain dan sebagainya.

\section{TINJAUAN PUSTAKA}

\section{Prilaku Kepemimpinan}

Menurut Mar'at (1999: 37) menyatakan bahwa pada dasarnya diskripsi dari tingkah laku seorang pemimpin disebut leadership traits. Pada umumnya faktor-faktor yang akan dipertimbangkan adalah: (a). Keadaan fisik dan konstitusional, misalnya berat badan, tinggi badan, tumbuhnya, energinya, kesehatan dan penampilan. (b) Kecerdasan. (c) Kepercayaan diri. (d) Penyesuaian diri. (e) Kemauan yang meliputi inisiatif dan ambisinya. (f) Memiliki kepribadian yang memiliki optimisme, dapat mengungkapkan sesuatu secara baik, memiliki originalitas, keterbukaaan, gembira dan merasa dirinya yakin. (g) Sifat-sifat situasional, yang berarti partisipasi sosial dalam situasi apa pun dapat menyesuaikan.

Ciri-ciri tersebut di atas biasanya merupakan persyaratan keberhasilan seorang pemimpin dan dapat diukur atau diobservasi di dalam aktivitasnya. Ketujuh ciri-ciri ini sebenarnya didapatkan dari hasil penelitian Angkatan Darat Amerika Serikat berdasarkan keberhasilan dalam memimpin. Lebih lanjut menurut Mar'at (1999: 47) menyatakan bahwa jika kita melihat prinsip-prinsip kepemimpinan yang dianut oleh TNI AD, maka terdapat sebelas nilai prinsip-prinsip kepemimpinan, yaitu: (a) Takwa, memelihara diri dari perbuatan-perbuatan yang dilarang oleh Tuhan Yang Maha Esa dan taat kepada segala perintah-perintah-Nya. (b) Ing Ngarsa Sung Tulada, sebagai pemuka selalu memberi suri teladan kepada yang dipimpinnya. (c) Ing Madya Mangun Karsa, di tengah-tengah yang dipimpinnya terjun langsung bekerja sama bahu-membahu. (d) Tut Wuri Handayani, dari belakang selalu memberi dorongan dan semangat kepada yang dipimpinnya. (e) Waspada Purba Wisesa, selalu berhati-hati dalam segala kondisi, meneliti dan membuat perkiraan keadaan (estimate) secara terus-menerus. (f) Anbeg Para Ma'arta, pandai menentukan mana yang menurut ruang waktu dan keadaan patut didahulukan. (g) Prasaja, bersifat dan bersikap sederhana serta rendah hati dan correct. (h) Satya, loyalitas timbal-balik dan bersikap hemat tidak ceroboh serta memelihara kondisi materil dengan kecermatan. (i) Balaka, bersifat dan bersikap terbuka, jujur dan siap menerima segala kritik yang membangun, selalu mawas diri dan selalu siap mempertanggungjawabkan perbuatannya.(j) Legawa, rela dan ikhlas untuk pada waktunya mengundurkan 
diri dari fungsi kepemimpinannya, dan diganti dengan suatu generasi baru, yang telah mewarisi kesepuluh prinsip ini.

Prinsip-prinsip kepemimpinan yang diuraikan diatas sebenarnya merupakan train of personality, dan untuk memenuhi persyaratan tersebut di atas maka menurut Mar'at (1999: 48) diperlukan syarat-syarat kepemimpinan sebagai berikut: Jujur, Berpengetahuan, Berani, Tegas, Dapat diandalkan, Berinisiatif,

Bijaksana, Adil, Gairah, Ulet, Tidak mementingkan diri sendiri, Setia, Berwibawa, Mampu membuat pertimbangan. Menurut Wahjosumidjo (1999: 61) menyatakan bahwa perilaku kepemimpinan ada dua, yaitu: (a) Konsiderasi. Konsiderasi adalah perilaku kepemimpinan yang cenderung ke arah kepentingan bawahan. Oleh karena itu ciri-ciri perilaku kepemimpinan ini adalah: (1) Ramah tamah, (2) Mendukung dan membela bawahan, (3) Mau berkonsultasi, (4) Mau mendengarkan bawahan, (5) Mau menerima usulan bawahan, (6) Memikirkan kesejahteraan bawahan, (7) Memperlakukan bawahan setingkat dirinya. (b) Struktur inisiasi. Struktur inisiasi adalah perilaku kepemimpinan yang cenderung lebih mementingkan tujuan organisasi dari pada memperhatikan bawahan. Oleh karena itu ciri-ciri perilaku kepemimpinan ini adalah: (1) Memberikan kritik pelaksanaan pekerjaan yang jelek (2) Menekankan pentingnya batas waktu pelaksanaan tugas-tugas kepada bawahan. (3) Selalu memberi tahu apa-apa yang dikerjakan bawahan, (4) Selalu memberi petunjuk bawahan bagaimana melakukan tugas, (6) Memberikan standar tertentu atas pekerjaan, (7) Meminta bawahan agar selalu menuruti dan mengikuti standar yang telah ditetapkan, (8) Selalu mengawasi apakah bawahan bekerja sepenuh kemampuan.

Uraian mengenai ciri-ciri kepemimpinan yang merupakan tingkah laku dari pemimpin menggambarkan sebenarnya suatu dinamika kegiatan dari seorang pemimpin berdasarkan kepemimpinannya. Penelitian tentang tingkah laku kepemimpinan yang dinyatakan berhasil telah banyak dilakukan dirumuskanlah dasar-dasar yang perlu dimiliki seorang pemimpin, kemudian dan akhirnya dinyatakan sebagai ciri-ciri kepemimpinan. Dengan sendirinya ada beberapa hal yang bersifat unuversal, namun terdapat pula beberapa yang bersifat spesial dan sangat tergantung pada situasi budaya, kelompok yang dipimpin dan tujuannya. Menurut Mar'at (1999: 49) menyatakan bahwa untuk keberhasilan dari kepemimpinan ini dapat ditentukan kriteria sebagai berikut: (a) Tercapainya sasaran yang merupakan keluaran dari hasil perjuangan kebersamaan antara pemimpin dan kelompoknya. (b) Semangat juang dari kelompoknya yang merupakan esprit de corps. (c) Kepuasan dari anggota-anggota kelompoknya.

Ketiga hal tersebut merupakan sasaran utama dari seorang pemimpin dimana sebenarnya secara eksplisit merupakan fungsi dari seorang pemimpin. Perkembangan suatu negara atas suatu masyarakat akan membutuhkan pula tipe-tipe kepemimpinan tersendiri. Oleh karena itu, pada negara-negara yang sedang berkembang diperlukan tipe-tipe kepemimpinan yang lain sifatnya dari pada tipe-tipe kepemimpinan negara-negara yang sudah maju.

\section{Motivasi}

Suatu organisasi dapat dikatakan bisa mencapai tujuan dengan baik (berhasil) jika di antara indikatornya yaitu sumber daya manusia, bisa dikelola dan didayagunaan dengan lebih baik. Seorang pimpinan sangat perlu memahami dan sekaligus mampu melaksanakan teknik-teknik untuk memelihara dan meningkatkan kinerja pegawai tersebut diantaranya dengan memberikan motivasi kepada karyawan, sehingga karyawan tersebut bisa terdorong untuk melaksanakan tugasnya dengan lebih baik. Tohardi (2002: 334) mendefinisikan motivasi adalah kekuatan (dorongan) yang kuat dari dalam diri seseorang untuk melakukan aktivitas sesuai dengan dorongan prilaku individu yang bersangkutan.

Menurut Siagian (2002: 102) definisi motivasi adalah daya dorong bagi seseorang untuk memberikan kontribusi yang sebesar mungkin demi keberhasilan organisasi mencapai tujuannya. Dengan pengertian, bahwa tercapainya tujuan organisasi berarti tercapai pula tujuan pribadi para anggota organisasi yang bersangkutan. Sedangkan menurut George R. Terry dan Leslie W. Rue seperti yang dikutip oleh Asnawi (2002: 18) definisi motivasi adalah sebagai daya perangsang atau daya pendorong, yang merangsang dan 
mendorong pegawai untuk mau bekerja dengan segiat-giatnya berbeda antara pegawai yang satu dengan yang lainnya.

Nimran (2001: 20) menyatakan bahwa pada dasarnya ada tiga karakteristik pokok yang harus terpenuhi dalam motivasi adalah sebagai berikut: (a) Usaha. Suatu usaha menunjukkan suatu kekuatan prilaku kerja seseorang dalam pekerjaannya. Dalam hal ini melibatkan berbagai macam kegiatan dan jenis pekerjaan. (b) Kemauan keras atau kuat . Kemauan keras atau kuat yang ditujukan oleh seseorang dalam menerapkan usahanya dalam tugas-tugas yang dilaksanakannya. (c) Arah dan tujuan. Tujuan yang ingin dicapai dengan usaha dan kemauan yang keras oleh seseorang pada dasarnya berupa hal-hal yang dapat membuahkan hasil yang lebih menguntungkan. Berdasarkan beberapa pendapat yang telah dikemukakan di atas maka dapat diambil suatu kesimpulan bahwa motivasi adalah: (a) Merupakan daya pendorong dalam diri seseorang untuk melakukan suatu perbuatan. (b) Merupakan perwujudan dari kegiatan yang kuat untuk mencapai suatu tujuan yang telah ditetapkan. (c) Sebagai sarana yang dapat digunakan untuk memadukan tujuan yang bersangkutan dengan tujuan organisasi atau kelompok. (d) Merupakan hal yang sepesifik tergantung pribadi yang bersangkutan.

\section{Kinerja}

Ada banyak pakar atau ahli yang telah mengemukakan berbagai pengertian kinerja dalam bukubuku mereka yang kelihatannya agak berbeda meskipun sebenamya sama. Perbedaan ini disebabkan karena mereka memandang kinerja dari segi yang berbeda. Simamora (2001: 327) mendefinisikan kinerja adalah merupakan suatu pencapaian persyaratan pekerjaan tertentu yang akhirnya secara langsung dapat tercermin dari keluaran yang dihasilkan baik jumlah maupun kualitasinya. Menurut Nawawi (1999: 234) definisi kinerja adalah suatu hasil pelaksanaan suatu pekerjaan baik yang bersifat material maupun non material. Sedangkan menurut Yastis (1999: 55) definisi kinerja adalah sebagai berikut: Kinerja adalah penampilan, hasil karya personil baik kuantitas maupun kualitas dalam suatu organisasi. Kinerja dapat merupakan penampilan individu maupun kelompok kerja personil. Penampilan hasil karya tidak terbatas kepada personil yang memangku jabatan fungsional maupun struktural tetapi juga kepada seluruh jajaran personil di dalam organisasi. Berdasarkan beberapa pendapat yang telah dikemukakan di atas maka dapat diambil suatu kesimpulan bahwa kinerja adalah hasil yang dicapai oleh seseorang dalam melaksanakan tugas menurut ukuran yang berlaku untuk pekerjaan yang bersangkutan.

Kinerja merupakan perwujudan kerja yang dilakukan oleh karyawan yang biasanya dipakai sebagai dasar penilaian terhadap pegawai atau organisasi. Kinerja yang baik merupakan suatu langkah menuju tercapainya tujuan organisasi. Oleh karena itu, kinerja merupakan penentu dalam mencapai tujuan organsasi. Sehingga perlu diupayakan peningkatkan kinerja, walaupun hal ini tidaklah mudah karena banyak faktor yang menyebabkan tinggi rendahnya kinerja seseorang. Banyak teori yang mengemukakan mengenai faktor yang mempengaruhi kinerja baik sebagai pribadi yang mempunyai karakteristik yang bersifat fisik maupun kejiwaan. Gomes (1998: 147) menyatakan bahwa kriteria pengukuran kinerja berdasarkan prilaku yang spesifik adalah sebagai berikut: (a) Quantity of work, yaitu jumlah kerja yang dilakukan dalam suatu periode waktu yang ditentukan. (b) Quality of work, yaitu kualitas kerja yang dicapai berdasarkan syarat-syarat kesiapannya. (c) Job knowledge, yaitu luasnya pengetahuan mengenai pekerjaan dan keterampilannya. (d) Creativeness, yaitu keaslian gagasan yang dimunculkan dan tindakan untuk menyelesaikan persoalan-persoalan yang timbul. (e) Cooperation, yaitu kesediaan untuk bekerja sama dengan orang lain (sesama anggota organisasi). (f) Dependability, yaitu kesadaran berdisiplin dan dapat dipercaya dalam kehadiran dan penyelesaian kerja. (g) Initiative, yaitu semangat untuk melaksanakan tugas-tugas baru dan dalam memperbesar tanggung jawabnya. (h) Personnel qualities, yaitu menyangkut kepribadian, kepemimpinan, keramahtamahan dan integritas pribadi.

Motivasi mempengaruhi kegiatan kerja seorang karyawan yang sudah tentu mempengaruhi hasil kerjanya. Soepriyanto (1998: 224) menyatakan bahwa kinerja (perfomance) atau prestasi kerja seseorang tergantung pada motivasi orang tersebut terhadap pekerjaan yang dilakukan. Hal ini berarti bahwa hubungan antara motivasi dengan kinerja seseorang adalah berbanding lurus di mana semakin besar atau 
tinggi motivasi seseorang melakukan pekerjaan tersebut semakin tinggi pula tingkat kinerjanya, demikian pula sebaliknya semakin kecil atau rendah motivasi seseorang melakukan pekerjaan tersebut semakin kecil atau rendah pula kinerjanya.

\section{METODE PENELITIAN}

\section{Definisi Operasional}

Untuk memberikan penjelasan mengenai indikator yang digunakan dalam penelitian dan usaha pemecahan masalah sesuai dengan judul penelitian ini, maka dirumuskan mengenai definisi operasional yang dapat dijabarkan sebagai berikut:

1. Perilaku kepemimpinan adalah suatu kegiatan atau aktivitas 11 Lurah di wilayah Kecamatan Samarinda Utara sehingga dapat menimbulkan kepatuhan, rasa hormat, loyalitas dan kerja sama dari pegawainya. Adapun indikator yang digunakan untuk mengukur perilaku kepemimpinan lurah ada dua, yaitu: (a) Konsiderasi adalah perilaku kepemimpinan lurah yang cenderung ke arah kepentingan bawahan, meliputi: Ramah tamah, Mendukung dan membela bawahan, Bersedia berkonsultasi, Bersedia mendengarkan bawahan, Bersedia menerima usulan bawahan, Memikirkan kesejahteraan bawahan, Memperlakukan bawahan setingkat dirinya. (b) Struktur inisiasi adalah perilaku kepemimpinan lurah yang cenderung lebih mementingkan tujuan organisasi dari pada memperhatikan bawahan, meliputi: Memberikan kritik pelaksanaan pekerjaan yang jelek, Menekankan pentingnya batas waktu pelaksanaan tugas-tugas kepada bawahan., Selalu memberi tahu apa-apa yang dikerjakan bawahan, Selalu memberi petunjuk bawahan bagaimana melakukan tugas, Memberikan standar tertentu atas pekerjaan, Meminta bawahan agar selalu menuruti dan mengikuti standar yang telah ditetapkan, Selalu mengawasi apakah bawahan bekerja sepenuh kemampuan.

2. Motivasi adalah merupakan tindakan yang dilakukan oleh 11 Lurah di wilayah Kecamatan Samarinda Utara untuk mendorong pegawainya agar dapat melakukan pekerjaan semaksimal mungkin sehingga tujuan yang telah ditetapkan dapat tercapai. Adapun indikator yang digunakan untuk mengukur motivasi ada tiga, yaitu: (a)Kebutuhan akan eksistensi (existence needs) adalah kebutuhan pegawai 11 Kantor Kelurahan di wilayah Kecamatan Samarinda Utara yang berhubungan dengan pembayaran, tunjangan dan kondisi kerja yang aman dan nyaman termasuk didalamnya physiological needs dan safety needs dari Maslow. Adapun kebutuhan akan eksistensi dalam penelitian ini meliputi: Pembayaran (gaji), Tunjangan, Kondisi kerja yang aman dan nyaman, Adanya jaminan sosial tenaga kerja, (b) Kebutuhan akan persaudaraan (relationship) adalah kebutuhan pegawai 11 Kantor Kelurahan di wilayah Kecamatan Samarinda Utara yang berhubungan dengan kebutuhan memiliki dan dapat mengadakan hubungan sosial dan keanggotaan kelompok yang melibatkan wakil pekerja, supervisor bahkan keluarga serta teman. Kebutuhan ini berkaitan juga dengan social needs dan esteem needs dari Maslow. Adapun kebutuhan akan persaudaaan dalam penelitian ini meliputi: Memiliki serikat pekerja , Adanya pengakuan atas serikat pekerja, Adanya kesempatan untuk mengembangkan diri, Adanya kesempatan untuk meningkatkan kemandirian, Adanya kesempatan untuk meraih kebebasan, (c) Kebutuhan akan pertumbuhan (growth) adalah kebutuhan pegawai 11 Kantor Kelurahan di wilayah Kecamatan Samarinda Utara yang berhubungan dengan pengembangan pegawai, karier pegawai dan dapat melakukan pekerjaan yang kreatif maupun aktivitas non kerja. Adapun kebutuhan akan pertumbuhan dalam penelitian ini meliputi: Adanya kesempatan untuk pengembangan SDM pegawai, Adanya kesempatan untuk pengembangan karier, Adanya kesempatan untuk pengembangan kreatifitas pegawai

3. Kinerja adalah suatu hasil yang dicapai oleh pegawai 11 Kantor Kelurahan di wilayah Kecamatan Samarinda Utara dalam melaksanakan tugas menurut ukuran yang ditetapkan untuk pekerjaan yang bersangkutan yang meliputi kualitas kerja, kuantitas kerja dan disiplin kerja. Adapun indikator yang digunakan untuk mengukur kinerja pegawai adalah: (a) Quantity of work, yaitu pekerjaan dapat diselesaikan setiap harinya. (b) Quality of work, yaitu pekerjaan sudah memenuhi kualitas yang 
diinginkan. (c) Job knowledge, yaitu memiliki kemampuan dan keterampilan yang sesuai untuk bidang pekerjaannya. (d) Creativeness, yaitu memiliki kreatifitas untuk menyelesaikan dan memecahkan persoalan yang dihadapi dalam pekerjaan. (e) Cooperation, yaitu kesediaan untuk bekerja sama dengan orang lain (sesama anggota organisasi). (f) Dependability, yaitu kesadaran berdisiplin dan dapat dipercaya dalam kehadiran dan penyelesaian kerja. (g) Initiative, yaitu semangat untuk melaksanakan tugas-tugas baru dan dalam memperbesar tanggung jawabnya. (h) Personnel qualities, yaitu menyangkut kepribadian, kepemimpinan, keramahtamahan dan integritas pribadi.

\section{Populasi dan Sampel}

Dalam penelitian ini sebagai populasi adalah jumlah pegawai untuk masing-masing kelurahan yang ada di Kecamatan Samarinda Utara. Dalam penelitian ini penulis mengambil populasi sebagai obyek penelitian yaitu 175 orang pegawai yang tersebar di 11 Kantor Kelurahan yang ada di wilayah Kecamatan Samarinda Utara pada tahun 2016. Untuk lebih jelasnya dapat dilihat pada Tabel 1. berikut ini:

Tabel 1. Populasi Penelitian Pegawai yang Tersebar di 11 Kantor Kelurahan yang ada di Wilayah Kecamatan Samarinda Utara Pada Tahun 2008

\begin{tabular}{clcr}
\hline No & \multicolumn{1}{c}{ Kelurahan } & $\begin{array}{c}\text { Jumlah Pegawai } \\
\text { (Orang) }\end{array}$ & $\begin{array}{c}\text { Persentase } \\
(\boldsymbol{\%})\end{array}$ \\
\hline 1 & Sungai Pinang Dalam & 23 & 13,14 \\
2 & Pelita & 15 & 8,57 \\
3 & Temindung Permai & 19 & 10,86 \\
4 & Sempaja Selatan & 18 & 10,29 \\
\hline 5 & Sempaja Utara & 13 & 7,43 \\
6 & Lempake & 16 & 9,14 \\
7 & Mugirejo & 21 & 12,00 \\
8 & Tanah Merah & 10 & 5,71 \\
9 & Gunung Lingai & 12 & 6,86 \\
10 & Bandara & 15 & 8,57 \\
11 & Sungai Siring & 13 & 7,43 \\
\hline \multicolumn{2}{c}{ Jumlah } & $\mathbf{1 7 5}$ & $\mathbf{1 0 0 , 0 0}$ \\
\hline
\end{tabular}

Sumber: Kantor Camat Samarinda Utara, 2016.

\section{Teknik Pengumpulan Data}

Dalam usaha untuk memperoleh data yang dibutuhkan, maka untuk mendapatkan data tersebut dipergunakan teknik sebagai berikut: (a) Observasi yaitu pengumpulan data secara langsung pada obyek penelitian, (b) Dokumen yaitu suatu teknik yang menggunakan data yang ada diperusahaan tersebut sebagai informasi, (c) Kuisioner adalah mengumpulkan data dengan membagikan daftar pertanyaan untuk dijawab kepada responden.

\section{Alat Analisis Data}

Untuk mengetahui faktor - faktor yang paling berpengaruh pada pengawasan langsung dan pengawasan tidak langsung terhadap efektivitas kerja pegawai Dinas Pekerjaan Umum dan Pemukiman Prasarana Wilayah Kota Samarinda, digunakan penerapan alat analisis regresi berganda menurut Rangkuty (2002:162).

\section{HASIL DAN PEMBAHASAN}

Dengan menggunakan alat bantu SPSS, diperoleh persamaan regresi sebagai berikut: 


\section{$\mathrm{Y}=16,292+0,083 \mathrm{X} 1+0,117 \mathrm{X} 2$}

Hal ini berarti bahwa variabel perilaku kepemimpinan lurah (X1) dan variabel motivasi (X2) memberikan pengaruh positif terhadap kinerja pegawai (Y).

Konstanta sebesar 16,292 menyatakan bahwa jika tidak ada variabel perilaku kepemimpinan lurah (X1) dan variabel motivasi (X2), maka kinerja pegawai adalah 16,292, sedangkan koefisien regresi X1 sebesar 0,083 dan X2 sebesar 0,117. Hal ini berarti bahwa setiap penambahan (karena tanda + ) perilaku kepemimpinan lurah (X1) dan variabel motivasi (X2) akan meningkatkan kinerja pegawai masing-masing sebesar 0,083 dan 0,117 .

Selanjutnya dari hasil analisis data diperoleh nilai R Square menunjukkan hasil sebesar $8,30 \%$ hal ini mengandung arti bahwa variabel perilaku kepemimpinan lurah (X1) dan variabel motivasi (X2) dapat menerangkan variabel kinerja pegawai (Y) sebesar 8,30\%, sedangkan sisanya 91,70\% diterangkan oleh variabel yang tidak diteliti dalam penelitian ini misalnya tingkat pendidikan dan beban kerja.

Nilai R sebesar 0,373 hal ini berarti bahwa terdapat hubungan yang rendah dari variabel perilaku kepemimpinan lurah (X1) dan motivasi (X2) terhadap kinerja pegawai (Y) sebesar 0,373. Hal ini sesuai dengan interprestasi Arikunto (2002: 236), bahwa nilai hubungan dengan interval 0,200 - 0,399 masuk dalam katagori rendah. Terjadinya hubungan yang rendah dari variabel perilaku kepemimpinan lurah dan motivasi terhadap kinerja pegawai disebabkan karena responden adalah pegawai negeri sipil dan honorer yang bekerja di institusi pemerintahan yang tingkat persaingan pegawai kurang dan biasanya para pegawai kelurahan bekerja secara rutinitas biasa.

Untuk menguji kemaknaan hipotesis yang digunakan yaitu uji-F (uji bersama-sama) dengan membandingkan nilai Fhitung dengan Ftabel dengan tingkat signifikansi 95\% atau $\alpha=0,05$ derajat kebebasan (df) untuk pembilang 2 dan untuk penyebut 172, diperoleh nilai Fhitung $=13,876>$ F0,05 (2) $(172)=3,000$, hal ini berarti bahwa variabel perilaku kepemimpinan lurah (X1) dan variabel motivasi (X2) secara bersama-sama berpengaruh signifikan terhadap kinerja pegawai, dengan demikian bahwa variabel perilaku kepemimpinan lurah (X1) dan variabel motivasi (X2) secara bersama-sama dapat dipergunakan untuk menilai kinerja pegawai, sehingga hipotesis penulis diterima. Hal ini menunjukkan walaupun hubungan yang rendah dari variabel perilaku kepemimpinan lurah dan motivasi terhadap kinerja pegawai akan tetapi variabel perilaku kepemimpinan lurah dan motivasi tetap memiliki pengaruh terhadap kinerja pegawai kelurahan.

Selanjutnya dengan memperhatikan uji t untuk menguji signifikansi konstanta dan variabel independen, dimana hipotesisnya adalah:

HO : Koefisien regresi tidak signifikan

Ha : Koefisien regresi signifikan

Dengan dasar pengambilan keputusan berdasarkan probabilitas, yaitu:

H0 : diterima, jika probabilitas $>\alpha=0,05$

H0 : ditolak, jika probabilitas $<\alpha=0,05$

Atau jika dasar pengambilan dengan $\mathrm{t}$ tabel, syaratnya adalah:

HO : diterima, jika thitung $\leq$ ttabel

H0 : ditolak, jika thitung $>$ ttabel

Berdasarkan analisis secara parsial, diketahui bahwa variabel perilaku kepemimpinan lurah (X1) mempunyai nilai thitung sebesar 2,892 jika dibandingkan dengan ttabel, dengan derajat kebebasan $(\mathrm{n}-\mathrm{k})=$ $175-2=173$ dan $\alpha / 2=0,05 / 2=0,025$ sebesar 1,960 . Dengan demikian thitung $>$ ttabel, sehingga dapat disimpulkan bahwa variabel perilaku kepemimpinan lurah (X1) berpengaruh secara signifikan terhadap variabel kinerja pegawai (Y). Hal ini berarti bahwa baik atau tidaknya kinerja pegawai kelurahan dapat digambarkan oleh baik atau tidaknya perilaku kepemimpinan lurah, karena memiliki hubungan yang searah. Adanya hubungan yang searah terjadi sebagai bentuk seimbangnya hubungan antara kinerja pegawai kelurahan dan perilaku kepemimpinan lurah, hal ini dapat dilihat dari mayoritas penilaian terhadap kinerja pegawai kelurahan dan perilaku kepemimpinan lurah sama-sama cukup baik. Data ini 
menunjukkan bahwa perilaku kepemimpinan lurah berhasil mempengaruhi kinerja pegawai dalam artian pegawai mau mengerjakan apa yang telah menjadi tugasnya, hal ini sesuai dengan pendapat Mar'at (1999: 11) yang menyatakan bahwa mendefinisikan kepemimpinan sebagai seni untuk mempengaruhi orang lain untuk mengerjakan apa yang diharapkan.

Untuk variabel motivasi (X2) diketahui nilai thitung > ttabel, yaitu 3,647 > 1,960 sehingga dapat disimpulkan bahwa variabel motivasi (X2) berpengaruh secara signifikan terhadap variabel kinerja pegawai (Y). Hal ini berarti bahwa baik atau tidaknya kinerja pegawai kelurahan dapat digambarkan oleh baik atau tidaknya motivasi yang diberikan lurah, karena memiliki hubungan yang searah. Adanya hubungan yang searah terjadi sebagai bentuk seimbangnya hubungan antara kinerja pegawai kelurahan dan motivasi yang diberikan lurah, hal ini dapat dilihat dari mayoritas penilaian terhadap motivasi yang diberikan lurah adalah baik maka kinerja pegawai kelurahan adalah cukup baik. Data ini menunjukkan bahwa motivasi yang diberikan Lurah berhasil mempengaruhi kinerja pegawai dalam artian pegawai berusaha untuk memberikan kontribusi yang sebesar mungkin demi keberhasilan organisasi mencapai tujuannya, hal ini sesuai dengan pendapat Siagian (2002: 102) yang menyatakan bahwa motivasi merupakan daya dorong bagi seseorang untuk memberikan kontribusi yang sebesar mungkin demi keberhasilan organisasi mencapai tujuannya. Dengan pengertian, bahwa tercapainya tujuan organisasi berarti tercapai pula tujuan pribadi para anggota organisasi yang bersangkutan

Dari kedua variabel tersebut, maka diketahui variabel motivasi (X2) berpengaruh dominan dibandingkan variabel perilaku kepemimpinan lurah (X1), hal ini dapat dilihat dari nilai thitung dimana nilai thitung untuk variabel motivasi (X2) yaitu 3,647 yang lebih besar dari pada nilai thitung untuk perilaku kepemimpinan lurah (X1) adalah 2,892, sehingga hipotesis penulis diterima.

Berdasarkan pembahasan di atas, maka dapat diketahui bahwa variabel perilaku kepemimpinan lurah dan motivasi secara bersama-sama maupun secara parsial mempunyai pengaruh yang signifikan terhadap kinerja pegawai Kelurahan di Kecamatan Samarinda Utara, sehingga hipotesis penulis dalam hal ini diterima.

\section{SIMPULAN}

Berdasarkan hasil penelitian serta analisis dan pembahasan mengenai pengaruh penilaian pegawai tentang perilaku kepemimpinan Lurah dan motivasi terhadap kinerja pegawai Kelurahan di Kecamatan Samarinda Utara yang telah dikemukakan pada bab terdahulu, maka dapat diambil kesimpulan adalah sebagai berikut:

1. Nilai $\mathrm{R}$ Square menunjukkan hasil sebesar $8,30 \%$ hal ini mengandung arti bahwa variabel perilaku kepemimpinan lurah (X1) dan variabel motivasi (X2) secara bersama-sama memberikan pengaruh terhadap kinerja pegawai (Y) sebesar 8,30\%, sedangkan sisanya 91,70\% diterangkan oleh variabel yang tidak diteliti dalam penelitian ini. Nilai R sebesar 0,373 hal ini berarti bahwa terdapat hubungan yang rendah dari variabel perilaku kepemimpinan lurah (X1) dan motivasi (X2) terhadap kinerja pegawai (Y) sebesar 0,373. Hal ini sesuai dengan interprestasi Arikunto (2002: 236), bahwa nilai hubungan dengan interval 0,200 - 0,399 masuk dalam katagori rendah. Adapun persamaan regresi linear ganda yang diperoleh dalam penelitian ini adalah: $\mathrm{Y}=16,292+0,083 \mathrm{X} 1+0,117 \mathrm{X} 2$

2. Berdasarkan uji F menunjukkan nilai Fhitung > Ftabel yaitu 13,876 > F0,05 (2) (172) = 3,000, hal ini berarti bahwa variabel perilaku kepemimpinan lurah (X1) dan variabel motivasi (X2) secara bersamasama berpengaruh signifikan terhadap kinerja pegawai, dengan demikian bahwa variabel perilaku kepemimpinan lurah (X1) dan variabel motivasi (X2) secara bersama-sama dapat dipergunakan untuk menilai kinerja pegawai, sehingga hipotesis penulis diterima.

3. Berdasarkan analisis secara parsial, diketahui bahwa variabel perilaku kepemimpinan lurah (X1) dan variabel motivasi (X2) berpengaruh signifikan terhadap kinerja pegawai (Y) karena memiliki nilai thitung > ttabel, dimana nilai thitung variabel perilaku kepemimpinan lurah adalah 2,892 sedangkan nilai ttabel sebesar 1,960. Untuk thitung variabel motivasi adalah 3,647 sedangkan nilai ttabel sebesar 1,960 sehingga hipotesis penulis diterima. 
4. Dari kedua variabel tersebut, maka diketahui variabel motivasi (X2) berpengaruh dominan dibandingkan variabel perilaku kepemimpinan lurah (X1), hal ini dapat dilihat dari nilai thitung dimana nilai thitung untuk variabel motivasi (X2) yaitu 3,647 yang lebih besar dari pada nilai thitung untuk variabel perilaku kepemimpinan lurah (X1) adalah 2,892, sehingga hipotesis penulis diterima.

\section{SARAN}

berikut:

Berdasarkan kesimpulan yang telah dibuat, maka dapat dikemukakan beberapa saran sebagai

1. Dari hasil penelitian diketahui bahwa variabel perilaku kepemimpinan lurah dan variabel motivasi memberikan pengaruh positif terhadap kinerja pegawai, sehingga bagi Lurah di wilayah Kecamatan Samarinda Utara harus memperhatikan dan mempertahankan variabel perilaku kepemimpinan lurah dan variabel motivasi.

2. Disarankan untuk penelitian yang akan datang untuk menambahkan variabel independen agar diperoleh hasil yang lebih akurat.

\section{DAFTAR PUSTAKA}

Arikunto, Suharsimi, 2002, Prosedur Penelitian Suatu Pendekatan Praktek, Cetakan Kesembilanbelas, Bina Aksara, Jakarta.

Asnawi, Sahlan, 2002, Teori Motivasi, Edisi Kedua, Cetakan Ketiga, Studia Press, Jakarta.

Gomes, Faustino Cardoso, 1998, Manajemen Sumber Daya Manusia, Cetakan Pertama, Andi Offset, Yogyakarta.

Mar'at, 1999, Pemimpin dan Kepemimpinan, Ghalia Indonesia, Jakarta.

Nawawi, Handari, 1999, Manajement Personalia (MSDM), Edisi Ketiga, Ghalia Indonesia, Jakarta.

Nimran, Umar, 2001, Perilaku Organisasi, Cetakan Ketiga, Citra Media, Surabaya.

Rangkuti, Fredy, 2002, Riset Pemasaran, Cetakan Keenam, Penerbit Gramedia, Jakarta.

Siagian, Sondang P., 2002, Kiat Meningkatkan Produktivitas Kerja, Cetakan Keempat, Rineka Cipta, Jakarta.

Simamora, Henry, 2001, Manajemen Sumber Daya Manusia, Edisi Kedua, Cetakan Ketiga, Sekolah Tinggi Ilmu Ekonomi YKPN, Yogyakarta.

Soeprihanto, John, 1998, Penilaian Pelaksanaan Pekerjaan dan Pengembangan Karyawan, Edisi Kedua, BPFE-UGM, Yogyakarta.

Tohardi, Achmad, 2002, Pemahaman Praktis Manajemen Sumber Daya Manusia, Cetakan Kelima, Mandar Maju, Bandung.

Yastis, Ilyas, 1999, Teori Penilaian dan Penelitian, Edisi Revisi, FKM UI, Jakarta. 